\title{
Money Check Result Data Management Application Section Verbasar By Web-Based (Case Study : Perum Peruri)
}

\author{
Topan Setiawan ${ }^{1}$ \\ Study Program \\ Information Systems \\ Faculty of Computer Science, \\ Universitas Ma'some, \\ Bandung, Indonesia \\ topansetiawan@masoemuniversity.ac.id
}

\author{
Nono Heryana ${ }^{2}$ \\ Study Program \\ Information Systems \\ Faculty of Computer Science, \\ Universitas Singaperbangsa \\ Karawang, Indonesia \\ nono@unsika.ac.id
}

\author{
Bayu Priyatna ${ }^{3}$ \\ Study Program \\ Information Systems \\ Faculty of Engineering and Computer \\ Science, Universitas Buana Perjuangan \\ Karawang, Indonesia \\ bayu.priyatna@ubpkarawang.ac.id
}

\begin{abstract}
Abstrak-Pemanfaatan teknologi komputer dan sistem informasi di abad ke-20 ini sudah banyak digunakan, tidak terkecuali pada perusahaan. Keuntungan dari penggunaan sistem informasi di perusahaan yaitu dapat menyajikan media pengelolaan data dalam proses bisnis perusahaan di mana sangat diperlukan agar efektifitas dapat tercapai. Seksi Verbasar merupakan salah satu seksi di Perum Peruri yang bertugas memeriksa hasil cetakan uang kertas, dengan jumlah karyawan sekitar 100 orang. Pengelolaan dan penyimpanan data hasil pemeriksaan uang di Seksi Verbasar masih terdapat permasalahan. Permasalahannya ialah penggunaan Microsoft Excel sebagai media pengelolaan dan penyimpanan data yang dinilai belum optimal. Oleh karena itu dibangun sebuah aplikasi pengelolaan data hasil pemeriksaan uang Seksi Verbasar berbasis web sebagai pengganti sistem lama agar pengelolaan dan penyimpanan data menjadi lebih optimal dalam proses dan laporannya. Pada pembuatan aplikasi ini peneliti menggunakan metode pengambilan data seperti observasi, wawancara, dan studi literatur. SDLC (System Development Life Cylce) model Waterfall digunakan untuk metode pengembangan sistem dengan UML (unified modelling language) sebagai modelling tools untuk mengembangkan rancangan sistem informasi. Hasil yang diharapkan adalah agar pengelolaan data hasil pemeriksaan uang dapat memberikan sistem yang lebih baik dari sistem lama dalam hal pengelolaan data.
\end{abstract}

Kata kunci : Aplikasi, SDLC, Waterfall, Web, Pemeriksaan, Uang

Abstract-The use of computer technology and information systems in the 20th century has been widely used, including companies. The advantage of using an information system in the company is that it can provide data management media in its business processes where effectiveness must be achieved. The Verbasar section is one of the sections in Perum Peruri, which is in charge of checking the printouts of banknotes, with around 100 employees. There are still problems in managing and storing data on the results of money checks in the Verbasar Section. The problem is using Microsoft Excel as a medium for data management and storage, which is considered not optimal. Therefore, a web-based application for data management of the Verbasar Section money examination results was built as a substitute for the old system so that data management and storage became more optimal in the process and report. In making this application, researchers used data collection methods such as observation, interviews, and literature studies. SDLC (System Development Life Cycle) Waterfall model is used for system development method with UML (unified modeling language) as modeling tools to develop information system design. The expected result is that the data management of money check results can provide a better system than the old system in terms of data management..

Keywords : Application, SDLC, Waterfall, Web, Examination, Money

\section{INTRODUCTION}

The rapid and widespread use of computer technology has created a new pattern of life where almost every activity, especially in terms of work, cannot be separated from information systems. The current information system plays a role as a supporter or assistant in time efficiency and working methods.

Many companies are already using information systems to support all production activities that run in the company [1]. An information system is an organized system that functions in managing information where the information can be useful and has the intent and purpose so that the 
information conveyed can be accepted and achieved [2]. One real example of the use of information systems is in the company. In companies, the use of information systems has become used at this time as a supporting medium for the running of business processes. [3].

Verbasar section is one of the sections in Perum Peruri which is in charge of verifying or checking the printed money [4]. The problem in the Big Sheet Verification Section (Verbasar) is that the data management of money check results is still using Microsoft Excel (Ms. Excel), which is considered ineffective [5]. Data on the results of money checks are data on the amount of money (quantity) that each employee and data have checked on cash damage found during the inspection. The use of Ms. Excel as a data management media is more at risk of being changed or even deleted, either intentionally or unintentionally, because anyone can open the data.

In addition, the large number of files stored on the computer makes searching for data difficult. Then in terms of the admin's ability to operate Ms. Excel, which is still inadequate, it makes data management more difficult so that the data report on the results of money checks is hampered [6]. Considering these problems, an internal information system application is needed in the Verbasar Section to manage money audit data so that data management becomes more effective and reduces the number of files stored. Therefore, this research takes the title "Web-Based Application for Data Management of Verbasar Section Money Check Results."

\section{METHOD}

\section{A. Data Collection Techniques}

Data collection techniques carried out in this study are as follows.

\section{Observation}

Observation is to make direct observations in the Verbasar Verification Section as a place of research. This observation is intended to obtain information related to the problems that are the object of research.

\section{Interview}

At the interview stage, the researcher conducted interviews with the leadership and admin of the verbasar section, regarding the data management of the ongoing money check results. The purpose of this interview is to obtain factual information.

\section{Literature Study}

This literature study carries out activities of collecting research bases from journals, books, final assignments, proceedings that have a relationship with the research title appointed. Information obtained from various sources, both national and international.

\section{B. System Development Method}

The system development method used in this research is the waterfall model SDLC (System Development Life Cycle). The SDLC method aims to produce a quality system that is by the customer's wishes [7]. The waterfall is analogous to a waterfall, and water will flow step by step until it finally reaches its destination [8]. SDLC Waterfall is a software development method that proposes a systematic and sequential approach to software starting from the level of system progress starting from analysis and ending with maintenance [9].

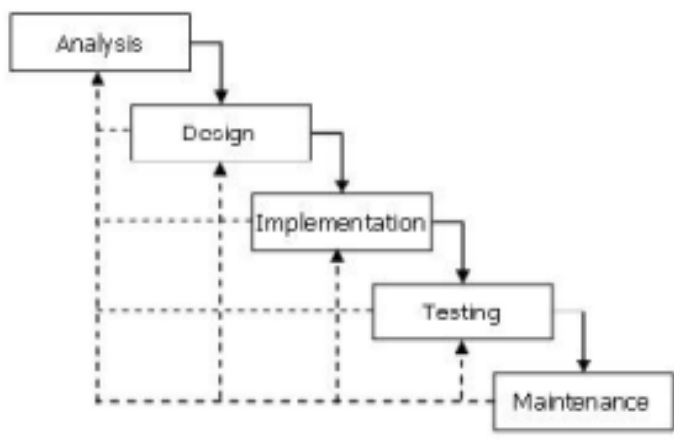

Figure 1 Stages of the SDLC Waterfall model [10]

The steps involved in making the application for data management results from money checks are as follows:

1. Analysis (Analysis)

At this stage collect information about the system that is running in the Verbasar Section by means of observation and interviews. Observations and interviews aim to obtain data that is in accordance with the facts in the Verbasar Section. After finding the problem, then it is analyzed to find a solution in the form of a proposed system.

\section{Design}

This stage is done before coding. This stage has 2 parts, namely system design and interface design. The system design is done with UML tools using 5 diagrams, namely use case diagrams, activity diagrams, sequence diagrams, and class diagrams. The second part is interface design, so that the interface is more effective, which means it is ready to be used with the desired results. The needs in question are the needs of users. The user interface on a system will affect the performance of its users. User interface design using the Pencil application.

\section{Implementation (Coding)}

In this stage, programming is carried out or the process of translating the design of the system design into a form that can be understood by the machine, using programming language codes. Making this program or application uses the Codeigniter framework, Bootstrap as a CSS framework, MYSQL as a database, PHP programming language, and Xampp as a web server.

4. Testing

Testing is the stage of feasibility testing on the system to be made, starting from the system design, to the function of each of its features. This test uses black box testing and white box testing methods. 


\section{Maintenance}

Maintenance is the final stage in the waterfall model by performing maintenance on the current system. System maintenance can be done by making repairs to parts that experience problems when running and backing up data regularly. Backing up data can take advantage of external storage such as a hard disk or by storing it in cloud storage (cloud storage).

\section{RESULTS AND DISCUSSION}

\section{A. System Planning}

At this stage is an activity to identify, analyze and evaluate problems or obstacles that occur in the current system, namely the process of managing data from the results of money checks. With the system analysis, it is hoped that improvements to the new system that will be designed can be proposed.

\section{Current System Analysis}

The following is a flowmap of the system running on the data management of the results of money checks in the Verbasar Section:

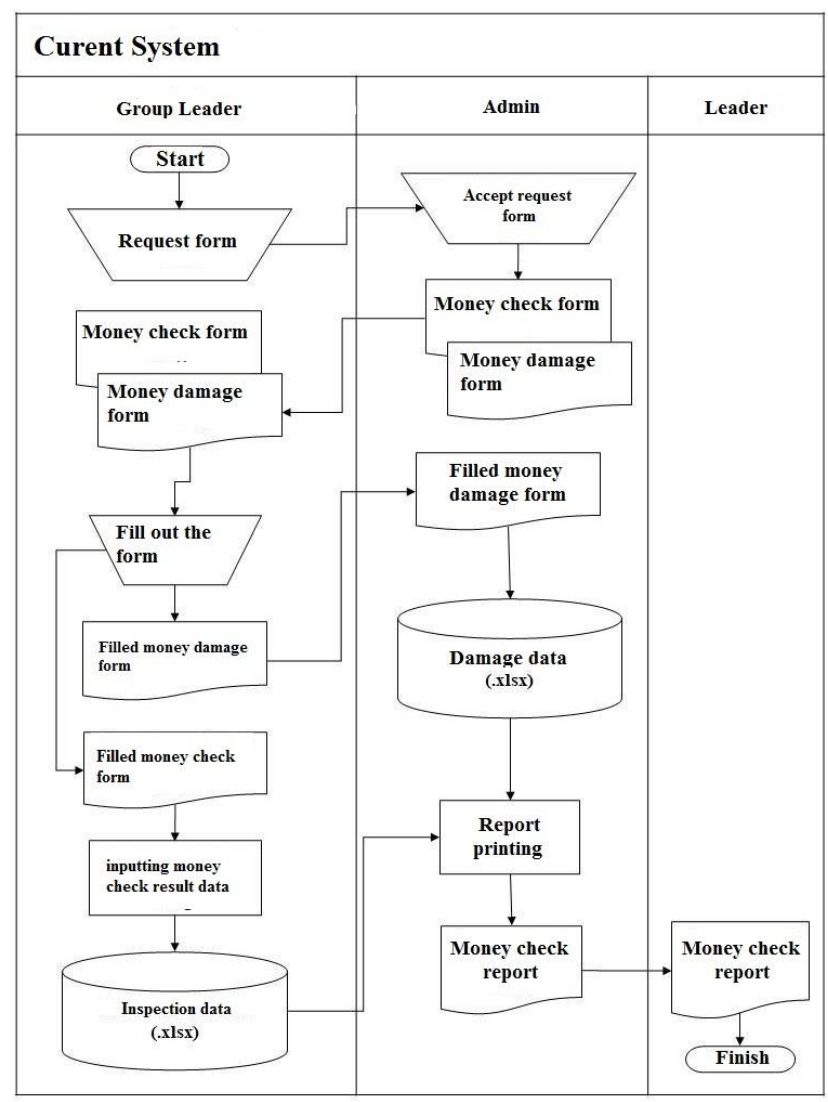

Figure 2 Flow maps of a running system

In the system that runs on the process of managing the data on the results of the examination of money, the group leader asks for a form to write the data on the results of the examination of money which consists of 2 forms, namely a form to write the amount of money checks carried out by employees and a form to write the amount of money damage. The inspection result data form is filled in by the group leader, then inputted into Microsoft Excel according to each group, and the money damage data form is given to the admin. Admin recaps data on damage to money and makes a report on the results of the inspection to be submitted to the leadership. Leaders receive reports and acc reports.

\section{Analysis of the proposed system}

Judging from the analysis that has been carried out on the system currently running in the Verbasar Section, it is proposed to make an application to be used as a medium or a place to manage data on the results of money checks. This application is a substitute for Ms. Excel as a data manager for money check results.

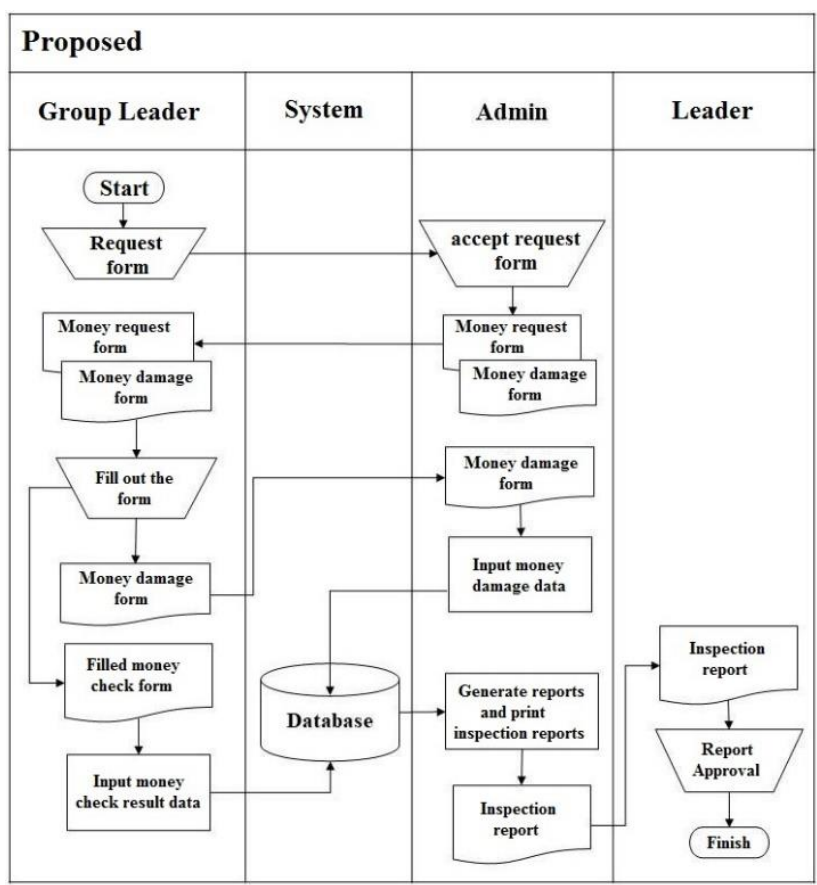

Figure 3 Flow maps of the proposed system

In the flowmaps, the proposed system for the data management application from the results of the money check requires 2 users, namely the admin and the group leader with their respective access rights. The first user or user is the group leader, where the task of the group leader is to input data on the results of money checks carried out by his group members. Each group leader will have their own account to be able to access the system or application. The second user is the admin, where the admin has the task of recapitulating the data on money damage obtained from each group leader and making reports to the leadership regarding the data on the results of money checks in the Verbasar Section.

\section{B. System Design}

The system modeling design uses UML (Unified Modeling Language) which is a standard modeling language used as a visualization, specifying, constructing, and documenting the tools of an object-oriented software system [11]. 


\section{Use case diagrams}

Use case diagrams only describe a condition seen by outside users, not how the functions that exist in the system [12]. The use case diagram for the application for managing data on the results of money checks consists of the admin and group leader.

a. Admin: managing employee data, checking group data, managing user data, managing group data, managing goods data, managing damage type data, managing damage data, and managing reports.

$b$. Group leader: The group leader is an actor who has access rights to manage data on the results of money checks that have been carried out by employees who are members of the group.

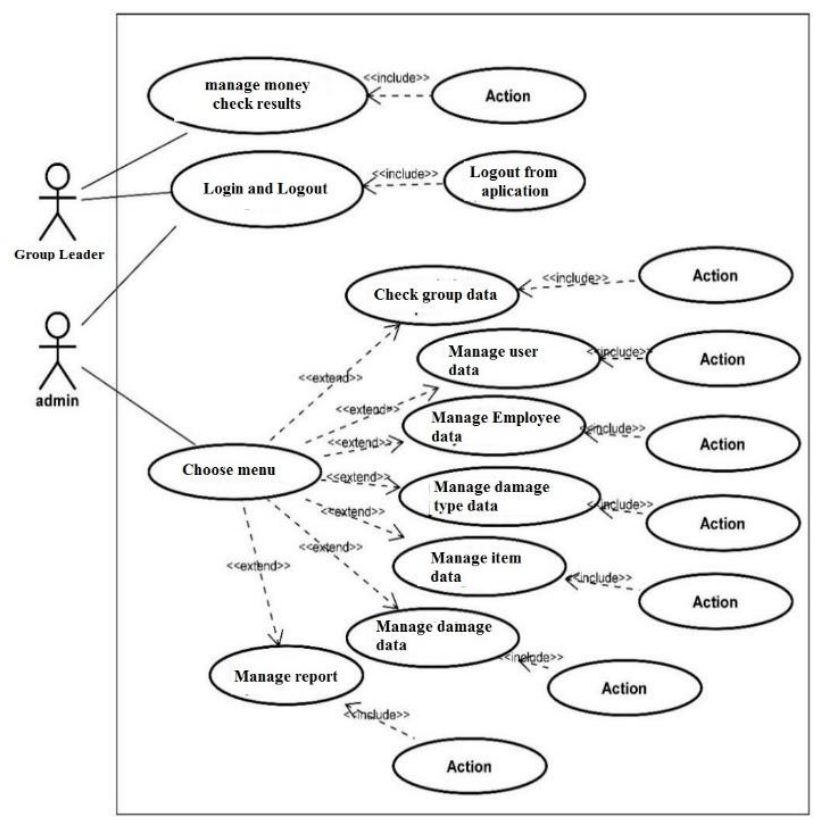

Figure 4 Use case diagrams

\section{Activity diagrams}

Activity diagram is a series of processes used to describe activities that are formed in a series of operations. Activity diagrams have the function of showing the sequence of process activities on the system, helping to understand the overall process [13]. The activity diagram below is an explanation of the process of managing money audit data which consists of adding, deleting data, and filtering data on money inspection results by the group leader.

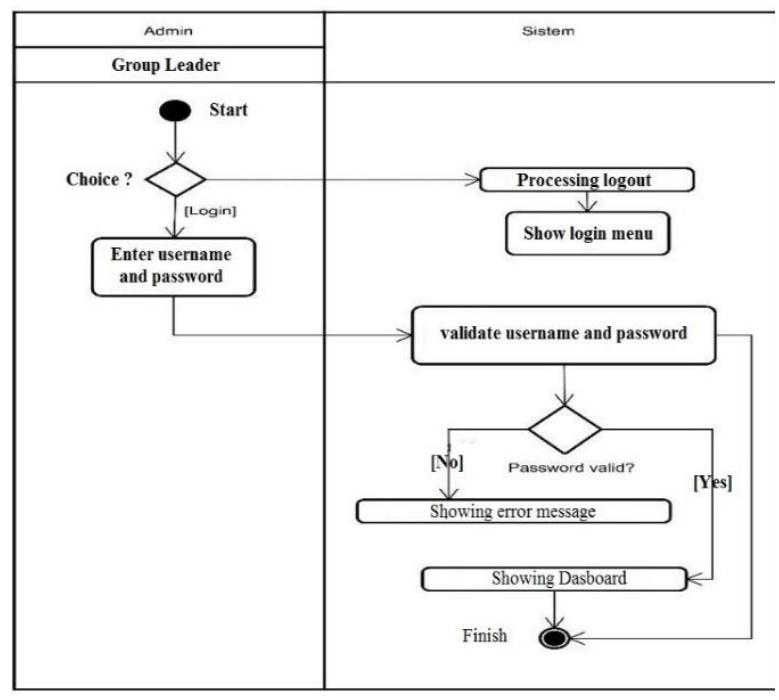

Figure 5 Activity diagram managing data from money check results

\section{Sequence diagram}

Sequence diagram is a diagram of the interaction between objects based on a certain time sequence. Sequence diagrams start from pulling the actors in the use case diagram by creating a detailed sequence of the flow of the use case process with messages flowing in it [14]. In the Sequence diagram, the data input of the results of the money check carried out by the employee is entered by the group leader into the application, and the data will be stored in the production table in the database.

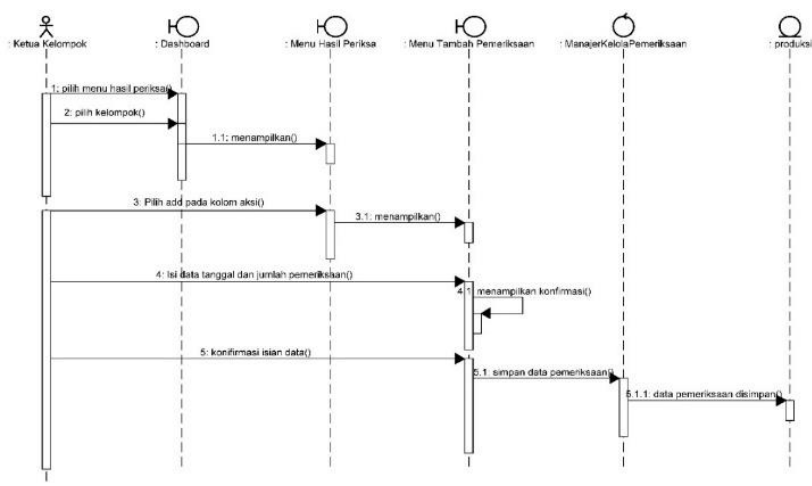

Gambar 1 Sequence diagram input data on money check results

\section{Class Diagrams}

A class diagram is a UML (Unified Modeling Language) diagram that defines the classes and the relationships between the classes to be built. The classes in the class diagram consist of attributes and methods to make creating programs that describe the relationship between design documentation and appropriate software [15]. The class diagram on the application for managing data on the results of money checks can be seen in the following figure. 


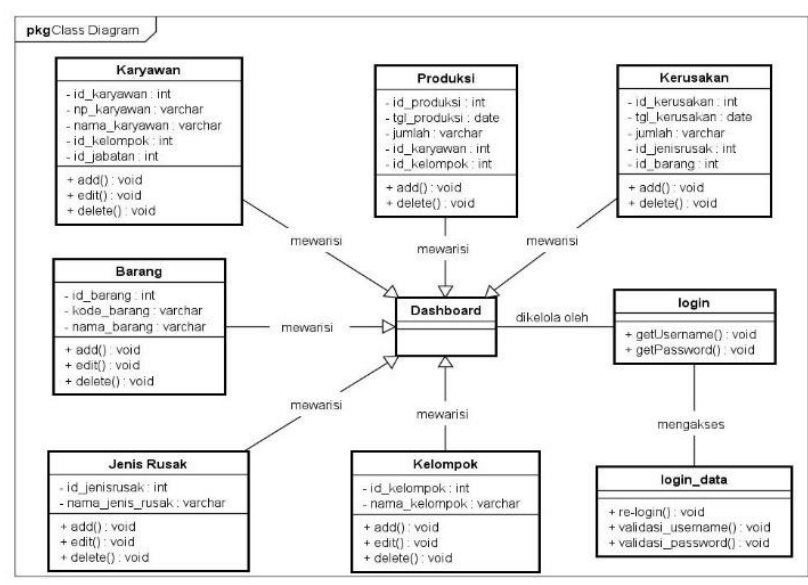

Figure 7 Class diagrams

5. Interface design

Interface design is an important part that will interact directly with users. The interface design that will be built on the Money Audit Result Data Management Application is as follows.

a. Main page display design with admin access:

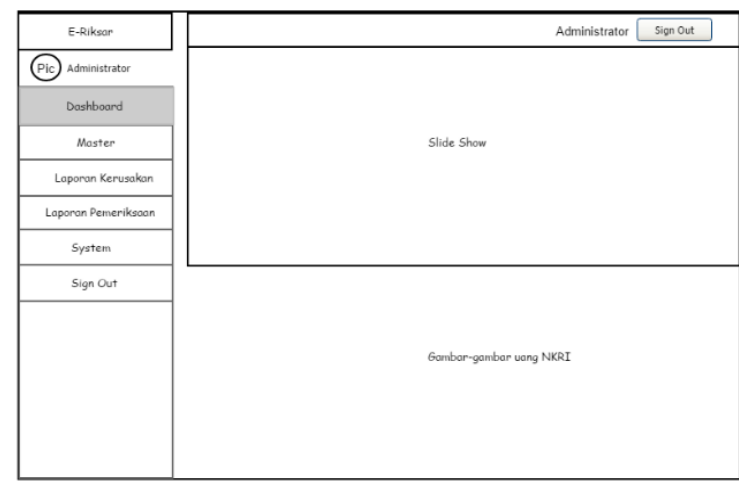

Figure 8 admin access main page

b. Main page display design with access as group leader:

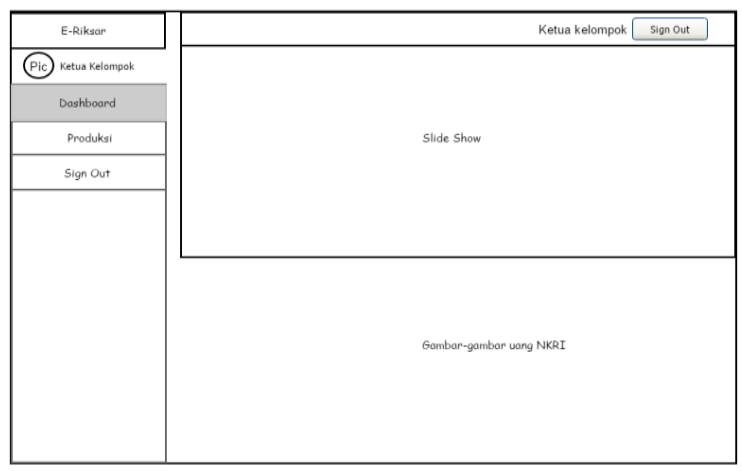

Figure 9 Main page access group leader

c. Money check results page done by employee:

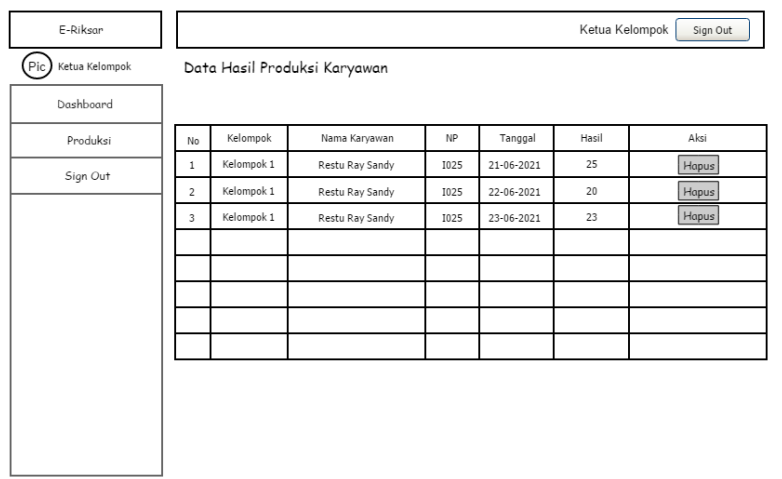

Figure 10 Data page of money check results

d. Damage data page which is the result of findings on money checks carried out by employees:

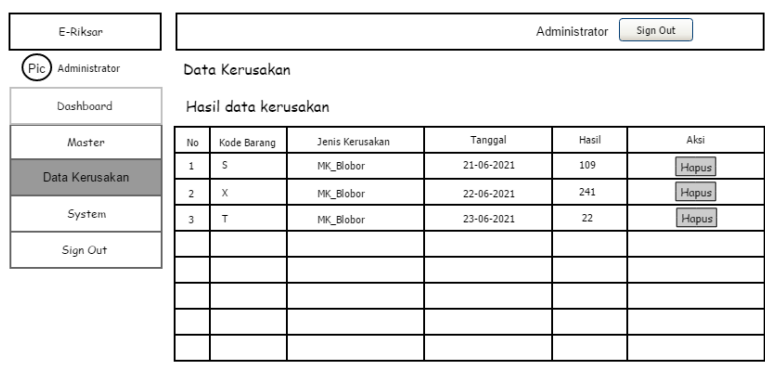

Figure 11 Money damage data page

\section{System Implementation}

System coding is the translation stage from the designer that has been made in the UML model and the system interface design. At this stage the application is made using the Codeighniter framework in which there is a PHP programming language combined with HTML, CSS, Boostrap and Javascript, for the base using MySQL.

\section{Login page}

The Login page is used by the user to enter the market retribution application according to the access rights owned by the user.

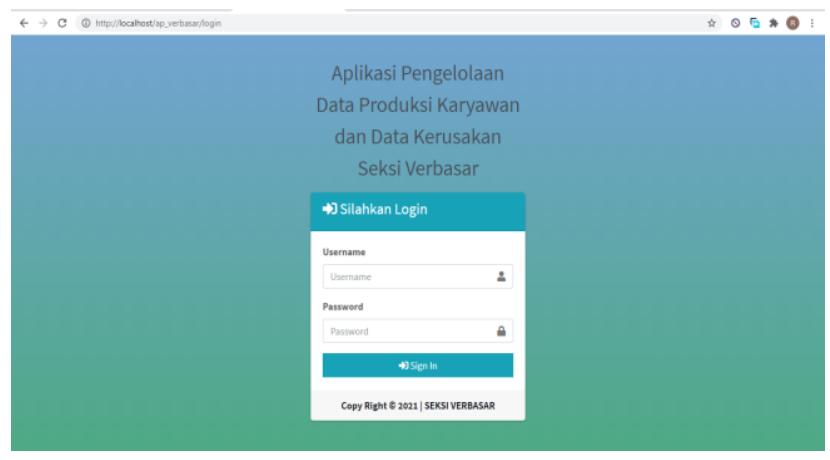

Figure 2 Login Page

2. Dashboard page

The dashboard page is the main page after the user has successfully logged in. 


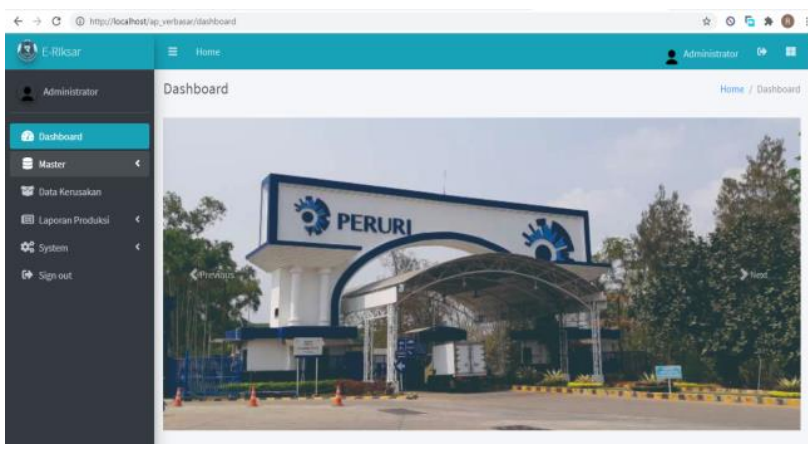

Figure 13 Admin dashboard page

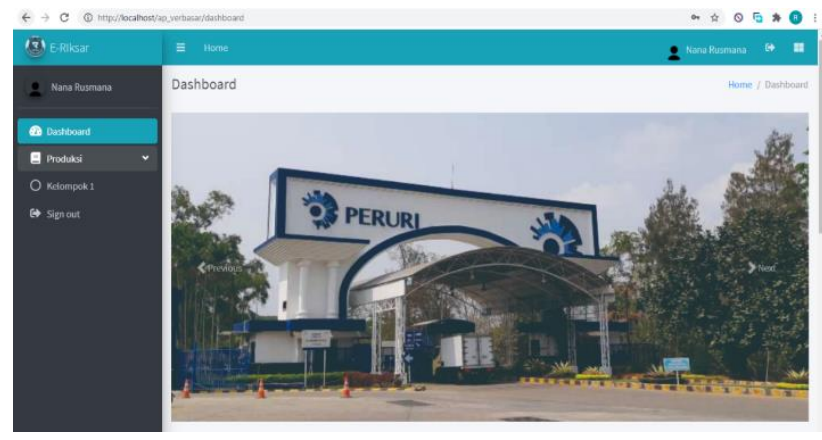

Figure 14 group leader dashboard page

3. Money check result page

This page contains data on the number of cash checks completed by employees.

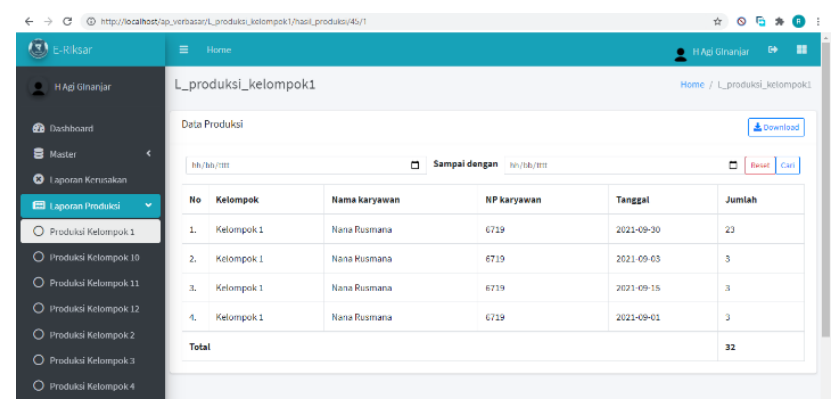

Figure 15 Officer access page

4. Money damage data page

This page will display data on cash damage collected from the results of money checks by employees.

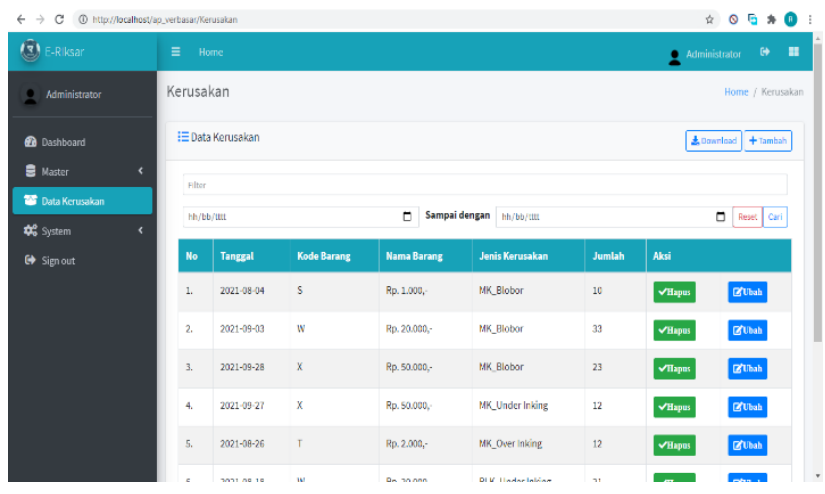

Figure 16 Money damage data page

\section{System testing}

System testing on the Money Check Result Data Management Application uses the black box method where the test is carried out on the program display to ensure the program runs well as desired. The testing process for this application is as follows.

Table 1 Testing the login page

\begin{tabular}{|l|l|l|}
\hline Process Design & Output & Result \\
\hline Open the app & Show login page & matching \\
\hline $\begin{array}{l}\text { Fill in username } \\
\text { and password } \\
\text { with correct } \\
\text { data }\end{array}$ & $\begin{array}{l}\text { A successful login } \\
\text { message appears and the } \\
\text { application dashboard } \\
\text { appears according to the } \\
\text { user }\end{array}$ & matching \\
\hline $\begin{array}{l}\text { Fill in username } \\
\text { and or password } \\
\text { with wrong data }\end{array}$ & $\begin{array}{l}\text { Dashboard fails to } \\
\text { appear, a message } \\
\text { appears that the } \\
\text { username or password } \\
\text { has not been registered }\end{array}$ & matching \\
\hline $\begin{array}{l}\text { Empty the } \\
\text { username and or } \\
\text { password }\end{array}$ & $\begin{array}{l}\text { Dashboard fails to } \\
\text { appear, a prompt } \\
\text { message appears to fill in } \\
\text { the username and } \\
\text { password form }\end{array}$ & matching \\
\hline
\end{tabular}

\section{E. Maintenance}

Maintenance on the system is carried out by correcting the program in case of errors, adding features as needed, and regularly backing up data. How to backup data by downloading the report on the results of the money check, then creating a report folder with the name of the date and month of the report. In addition, data related to the system, if there is a system update, data backups must be carried out, so that the data stored is the latest data. Backup data storage can use 2 ways, namely with external storage such as hard disks and cloud storage (cloud storage). Cloud storage is intended to avoid data loss when the hard drive is lost or damaged. System maintenance aims to maintain or even develop the system that has been created.

\section{CONCLUSION}

Based on the descriptions in the previous chapters, a problem was found in managing the data on the results of money checks in the Verbasar Section, which still uses Ms. Excel as a data management and data storage tool. This problem is the reason for creating a Web-Based Money Check Result Data Management Application. From the results of trials that have been carried out on the application, the following conclusions can be drawn:

1. This application can perform data processing on the results of money checks, including adding, changing, and deleting data. 
2. This application can display data reports on the results of money checks, which can be used to report to the leadership.

3. The data stored in this application is more efficient because the data is collected in one web-based storage source.

4. Reports on the results of money checks can be displayed based on a certain period with the provided data filter facility.

\section{REFERENCE}

[1] Suhendro, Dedi. 2017. "Perancangan Dan Implementasi Realisasi Anggaran Pendapatan ( Studi Kasus: Pengadilan Negeri Klas IB Pematangsiantar ).” Seminar Nasional Teknologi Informatika, 30-36.

[2] A. Lia Hananto et al., "Analysis of Drug Data Mining with Clustering Technique Using K-Means Algorithm," J. Phys. Conf. Ser., vol. 1908, no. 1, 2021.

[3] H. Bagir and B. E. Putro, "Analisis Perancangan Sistem Informasi Pergudangan di CV. Karya Nugraha," J. Media Tek. dan Sist. Ind., vol. 2, no. 1, p. 30, 2018.

[4] N. Nurhasanah and P. Inoprasetya, "Kompetensi, Komitmen Organisasi, dan Motivasi terhadap Kinerja Karyawan Verbasar Perum Peruri Karawang," Balanc. Econ. Business, Manag. Account. J., vol. 18, no. 1, p. 77, 2021.

[5] H. Mulyono, “124-335-1-Pb (1),” vol. 2, no. 4, pp. 771-780, 2017.

[6] MERRI PARIDA, S.Kom, and WILLIAMS KURNIA WARDANY. 2019. "Sistem Informasi Pengolahan Data Produksi Brebasis Web Pada Cv Semangat Jaya Lampung." Hilos Tensados 1: 1-476.

[7] A. H. Hendrawan, "Rancang Bangun Sistem Informasi Hasil Produksi Dengan Menerapkan Metode System Development Life Cycle," Ranc. Bangun Sist. Inf. Has. Produksi Dengan Menerapkan Metod. Syst. Dev. Life Cycle, pp. 1-7, 2016.

[8] Mujilan, Agustinus. 2017. Analisis dan Perancangan Sistem. Madiun: Fakultas Ekonomi dan Bisnis Universitas Katolik Widya Mandala.

[9] Huda, Baenil, and Saepul Aripiyanto. 2019. "BERBASIS ANDROID DAN WEB MONITORING (Penelitian Dilakukan Di Kab. Karawang).” Teknologi Informasi 4 (1): 11-24.

[10] Duha, N. J., Suryadi, S., Yanris, G. J., Simanjuntak, N. J., Suryadi, S., Silaen, G. J. Y., Manajemen, A., \& Komputerlabuhan, I. (2017). SISTEM PENGARSIPAN SURAT BAGIAN ORGANISASI DAN TATALAKSANA. 5(3), 26-36.

[11] D. W. T. Putra and R. Andriani, "Unified Modelling Language (UML) dalam Perancangan Sistem Informasi Permohonan Pembayaran Restitusi SPPD," J. TeknoIf, vol. 7, no. 1, p. 32, 2019.
[12] S. Rosyida and V. Riyanto, "Sistem Informasi Pengelolaan Data Laundry Pada Rumah Laundry Bekasi," JITK (Jurnal Ilmu Pengetah. dan Teknol. Komputer), vol. 5, no. 1, pp. 29-36, 2019.

[13] E. Erlinda, "Pengolahan Data Sensus Penduduk Menggunakan Bahasa Pemrograman Php Berbasis Web Pada Kecamatan Bukit Sundi Kabupaten Solok," J. Teknol. Dan Open Source, vol. 1, no. 1, pp. 46-57, 2018 .

[14] M. I. Hanafri, Triono, and I. Luthfiudin, "Rancang Bangun Sistem Monitoring Kehadiran Dosen Berbasis Web Pada STMIK Bina Sarana Global," J. Sisfotek Glob., vol. Vol.8, no. No.1, pp. 81-86, 2018.

[15] Sidik, Achmad, Edy Tekat, Bronto Waluyo, and Siti Susilawati. 2018. "Perancangan Sistem Informasi Manajemen Produksi Di PT Aneka Paperindo Sejahtera.” Jurnal Sisfotek Global 8 (2): 8-13. 